\section{DIGITAL COMMONS \\ @ UNIVERSITY OF SOUTH FLORIDA}

\section{ABO: Interactive Journal for Women in the Arts, 1640-1830}

Volume 2

Issue 1 Volume 2.1 (Spring 2012): Open Access

Article 8

2012

\title{
Teaching Eighteenth-Century Literature as a Feminist Scholar in the New Millennium
}

\author{
Alison Conway \\ University of Western Ontario, amconway@uwo.ca \\ Sharon Harrow \\ Shippensburg University, srharr@ship.edu \\ Nora Nachumi \\ Yeshiva University, nachumi@yu.edu \\ Laura Runge \\ University of South Florida, runge@usf.edu
}

Follow this and additional works at: https://digitalcommons.usf.edu/abo

Part of the Dramatic Literature, Criticism and Theory Commons, Educational Methods Commons, Feminist, Gender, and Sexuality Studies Commons, and the Literature in English, British Isles Commons

\section{Recommended Citation}

Conway, Alison; Harrow, Sharon; Nachumi, Nora; and Runge, Laura (2012) "Teaching Eighteenth-Century Literature as a Feminist Scholar in the New Millennium," ABO: Interactive Journal for Women in the Arts, 1640-1830: Vol.2: Iss.1, Article 8.

http://dx.doi.org/10.5038/2157-7129.2.1.7

Available at: https://digitalcommons.usf.edu/abo/vol2/iss1/8

This Pedagogy is brought to you for free and open access by Digital Commons @ University of South Florida. It has been accepted for inclusion in ABO: Interactive Journal for Women in the Arts, 1640-1830 by an authorized administrator of Digital Commons @ University of South Florida. For more information, please contact digitalcommons@usf.edu. 


\section{Teaching Eighteenth-Century Literature as a Feminist Scholar in the New Millennium}

\section{Keywords}

ASECS, feminism, pedagogy

\section{Creative Commons License}

\section{(c) (i) $\ominus$}

This work is licensed under a Creative Commons Attribution-No Derivative Works 3.0 License. 
The papers presented here originated in the 2011 Aphra Behn roundtable at American Society for Eighteenth-Century Studies (ASECS) in Vancouver, chaired by Kirsten T. Saxton. The session generated a lively and sustained discussion around important conflicts, beliefs, and practices in the classroom, and the editors of $A B O$ thought it merited a forum for even more widespread and enduring consideration.

These essays address the central question of how to be feminist in the $21^{\text {st }}$ Century classroom, and they articulate a series of overlapping responses that are thought-provoking, intelligent and inspiring. All raise concerns about the following broad topics: how to respond to the critical distancing from feminism; the need to engage students and ideas and how to do so; and the potential to use feminist eighteenth-century studies as a way of illustrating important concerns for today's students. The essays are also practical in that they offer specific strategies to use in the classroom.

The first paper, by Alison Conway of the University of Western Ontario, addresses the implications of current notions that feminist scholarship today is "past its sell date"; she considers what it feels like personally to be positioned as old-fashioned and queries what that shift of focus means for feminism in the academy and for maintaining an interest in and market for women's literature, noting for example the marked decline of explicitly feminist topics at the 2011 ASECS. In the second paper, Sharon Harrow of Shippensburg University of Pennsylvania speaks to the problem of some third-wave feminist voices who either claim that we are postfeminist or who dilute the socio-political realities with which feminisms have been concerned; she warns against the dangers of a post-feminist world that can claim such figures as Sarah Palin as feminists. Harrow shares the ways in which she uses specific collaborative performative assignments to help students to animate historical texts with an eye toward various contexts (colonial, political, and gendered). Nora Nachumi of Yeshiva University follows with a discussion of the tensions between her practices as a teacher of feminism/women's studies (i.e. her urge to let students use texts as a lens through which to see their own lives) and as a teacher of eighteenth-century literature (i.e. the imperative to historicize and to foster critical distance). While she can reconcile these two hats as a scholar, she claims that they often vie for supremacy in the classroom, especially with her particular student population. In the final essay, Laura Runge of the University of South Florida, analyzes the fatigue and tension she senses in students when it comes to discussions of race, class, and gender, and how this discomfort may manifest in fears of being labeled sexist or racist, grand obtuseness, or uncomfortable, truncated discussions of gender and race. Her essay notes that this fatigue parallels the shift in critical trends over the past decade, a move from openly feminist themes and issues to broader political analysis that incorporates feminist theory and critical race theory into globalization, disability, ecocritical and various historicist studies. Runge comments on both the benefits and dangers of our generally laudable scholarly moves toward complexity for our students' understanding of our work and their relation to $18^{\text {th }}$-century studies. (Toni Bowers, who participated in the original roundtable, was regretfully unable to include her work in this publication.) 